\title{
Cultivable Actinobacteria First Found in Baikal Endemic Algae Is a New Source of Natural Products with Antibiotic Activity
}

\author{
Denis V. Axenov-Gribanov ${ }^{10},{ }^{1}$ Daria V. Kostka, ${ }^{1,2}$ Ulyana A. Vasilieva,,3 \\ Zhanna M. Shatilina, ${ }^{1}$ Maria E. Krasnova, ${ }^{1}$ Ekaterina V. Pereliaeva, ${ }^{1}$ \\ Elena D. Zolotovskaya, ${ }^{1}$ Maria M. Morgunova, ${ }^{1}$ Olga O. Rusanovskaya, ${ }^{1}$ \\ and Maxim A. Timofeyev ${ }^{1,4}$ \\ ${ }^{1}$ Irkutsk State University, Karl Marx St. 1, 664003 Irkutsk, Russia \\ ${ }^{2}$ Irkutsk Regional Clinical Advisory and Diagnostic Center, Baykalskaya Str., 109 Irkutsk, Russia \\ ${ }^{3}$ Siberian Institute of Plant Physiology and Biochemistry, 132 Lermontov Str., 664033 Irkutsk, Russia \\ ${ }^{4}$ Baikal Research Centre, Lenin Str., 21, 664003 Irkutsk, Russia
}

Correspondence should be addressed to Denis V. Axenov-Gribanov; denis.axengri@gmail.com

Received 24 March 2020; Accepted 2 July 2020; Published 27 July 2020

Academic Editor: Todd R. Callaway

Copyright (c) 2020 Denis V. Axenov-Gribanov et al. This is an open access article distributed under the Creative Commons Attribution License, which permits unrestricted use, distribution, and reproduction in any medium, provided the original work is properly cited.

\begin{abstract}
Inadequate use of antibiotics has led to spread of microorganisms resistant to effective antimicrobial compounds for humans and animals. This study was aimed to isolate cultivable strains of actinobacteria associated with Baikal endemic alga Draparnaldioides baicalensis and estimate their antibiotic properties. During this study, we isolated both widespread and dominant strains related to the genus Streptomyces and representatives of the genera Saccharopolyspora, Nonomuraea, Rhodococcus, and Micromonospora. For the first time, actinobacteria belonging to the genera Nonomuraea and Saccharopolyspora were isolated from Baikal ecosystem. Also, it was the first time when actinobacteria of the genus Nonomuraea were isolated from freshwater algae. Some rare strains demonstrated activity inhibiting growth of bacteria and yeasts. Also, it has been shown that the strains associated with Baikal alga $D$. baicalensis are active against both Gram-positive and Gram-negative bacteria. According to this study and previously published materials, diversity of cultivable actinobacteria and rare strains isolated from D. baicalensis is comparable to that of cultivable actinobacteria previously isolated from plant sources of Lake Baikal. Also, it exceeds the cultivable actinobacteria diversity previously described for macroinvertebrates, water, or sediments of Lake Baikal. The large number of rare and active strains associated with the endemic alga $D$. baicalensis could be the promising sources for biopharmaceutical and biotechnological developments and discovery of new natural compounds.
\end{abstract}

\section{Introduction}

Screening, synthesis, and production of biologically active compounds and natural products represent one of the most important research trends in biopharmaceutical studies all over the world [1]. The necessity to develop new drugs is induced by rapidly growing multidrug resistance of microorganisms to antibiotics introduced into medical and clinical practice [2,3]. However, the search and development of new biologically active compounds is complicated because most ecosystems and microorganisms producing natural products are already well-analysed. This leads to the fact that the probability to find new biologically active compounds and producers in this studied communities is relatively low [4]. At the same time, the chemical modification methods and those used in bioinformatics to predict and obtain new bioactive natural products have a natural limitations. Accordingly, of particular interest is the search and development of new biologically active compounds from specific symbiotic microorganisms that inhabit ecosystems with specific evolutionary and ecological characteristics. One of the most promising places for 
biopharmaceutical search is unique and little studied ecosystem of the ancient Lake Baikal.

Lake Baikal is a UNESCO World Heritage site. It seems to be a unique natural laboratory characterized by particular conditions of the lake, such as low temperatures, low content of mineral and organic elements, high oxygen content in the entire water column, and the highest level of biodiversity of flora and fauna [5]. Lake Baikal is the largest center of speciation, endemism [6], and the "pantry" of the genetic resources of the world.

Inhabitants of Lake Baikal play an important role in the ecosystem stability. At the same time, inhabitants of lake presented by diverse flora and fauna are ecological niches for microorganisms. Thousands of algae species endemic to Lake Baikal are the hosts for microorganisms that can be used in human activity. Futhermore, the algae diversity is of great significance for the ecosystem.

As a primary trophic chain, algae play a major role in life of water reservoirs. Structural and functional features of this chain largely determine the appearance of a lake ecosystem [7]. Also, algocenoses are very sensitive biological indicators, and they can detect minor changes that cannot be detected using other methods [8]. In case of Lake Baikal, algae are actively involved in self-purification processes. They are a test-object for estimation of trophicity and biological productivity. Studies of systematic composition of Baikal algae began in the XIX century [9-19]. Currently, the algae flora of the lake is represented by 569 species and 162 subspecies with $35 \%$ rate of endemicity [20]. About half of these species were found in the open Baikal. Phytoplankton amounts to more than 100 true planktonic algae species. Several pictures of algae inhabiting Lake Baikal are shown in Figure S1.

However, until the present time, Baikal algae with their microbial communities were not in the focus of diversity and biomonitoring assays and did not rank as the source of new or symbiotic microorganisms species used for human needs $[21,22]$. Symbiotic strains of actinobacteria are of specific interest for biotechnology because these microorganisms are rich and productive sources of genetic material for new natural products and biologically active compounds [23].

Actinobacteria belong to the group of Gram-positive bacteria with high content of guanine and cytosine in DNA. Most actinobacteria are aerobes, whereas facultative anaerobes are found only among actinobacteria with short mycelial stage. Actinobacteria are well distributed phylum of bacteria that inhabit various ecological niches, including extreme ones $[24,25]$.

These bacteria form associations with plants in aquatic and terrestrial environment. They participate in recycling of substances, and their distinct feature is a wide range of constructive and energy metabolism [26]. Actinobacteria play an important role in biological cycle, especially in soils [27]. Thus, bacteria related to the genus Frankia are well known for their plant-symbiotic associations and nitrogenfixing abilities. Annual nitrogen accumulation in soil with participation of the associations can be around $150-300 \mathrm{~kg} /$ ha. Nodules are formed resulting from symbiosis between plant roots and actinobacteria related to the genus Frankia sp. Leghemoglobin is synthesized in these nodules. This protein protects nitrogenase against excessive amounts of molecular oxygen. Also, the role of the Microbacteriaceae family in Arabidopsis thaliana roots [28] was hypothesized.

In Baikal region, there were only single studies focused on assessment of cultivated actinobacteria diversity in highplant communities. Thus, in one of the recent studies conducted by Axenov-Gribanov et al. [29], a variety of actinobacteria in Pinus sylvestris pollen was estimated. The authors showed that the taiga forest of Baikal Siberia has not been well studied, and its actinobacteria population remains undescribed. At the same time, diversity of cultivated communities of actinobacteria symbiotic to Baikal dominant endemic algae was not assessed, while ecology and lifestyle of this group of organisms are of interest for both fundamental and applied studies. In focus of first study for Baikal algomicrobial communities, here we aimed to isolate cultivable strains of actinobacteria associated with endemic alga Draparnaldioides baicalensis and estimate their antibiotic properties.

\section{Materials and Methods}

2.1. Sampling Sites and Isolation of Actinobacteria. During the study, pure cultures of actinobacteria were isolated from dominant freshwater endemic alga Draparnaldioides baicalensis. D. baikalensis is a freshwater filamentous green alga from the genus Draparnaldioides, the member of family Chaetophoraceae, order Chaetophorales, and class Chlorophyceae. The alga D. baicalensis (Figure S2) has a short period of vegetation. This species dominates in the summer-autumn period in the littoral zone at depths of 2.5-3.0 to 6-10 m. The thallus species is bush type. Height of the thallus is $15-35 \mathrm{~cm}$; it attaches to stones. D. baicalensis is characterized by a powerful mucous case to protect the alga from the wave action. It has a reticulate-perforated chloroplast occupying the entire height of the cell [30,31]. Due to ability of this alga, in the nearest future, it will be a finished complex study of chemical analysis in focus of secondary metabolism and algomicrobial interactions.

The alga samples were collected near the village Bolshie Koty (Southern Baikal, 51.902940, 105.071179) in 2018. Algal strands were washed in sterile Baikal water, then rinsed with $70 \%$ ethyl alcohol 3 times for 15 seconds, and rinsed with sterile water again 3-5 times for 30 seconds, alternatively $[32,33]$. The biological material $(n=10$, average weight is $10 \mathrm{~g}$ ) was collected using sterile tweezers and placed into sterile Falcon-tubes, homogenized with glass pestle directly in Falcon-tubes, and stored in 3 volumes (average volume, $30 \mathrm{ml}$ ) of sterile $20 \%$ glycerol in a freezer at $-20^{\circ} \mathrm{C}$ during $1-2$ weeks before plating on solid nutrient media.

Actinobacteria strains were isolated by triplicate plating of $100 \mu \mathrm{L}$ of each sample on solid nutrient media. Because the current study was a primary for this source, we chose standard and typical conditions for isolation and cultivation of actinobacteria [34]. To isolate the actinobacteria strains, we used mannitol soy flour agar (MS) [34] and actinomycete isolation agar (Difco) supplemented with antibiotics cycloheximide $(50 \mu \mathrm{g} / \mathrm{mL})$ and phosphomycin $(100 \mu \mathrm{g} / \mathrm{mL})$. Also, aliquots of collected samples $(500 \mu \mathrm{L})$ were preheated 
for $5 \mathrm{~min}$ at $50^{\circ} \mathrm{C}$ to activate spore germination and inactivate vegetative cells of other bacteria. The plates were incubated for 30 days at $28^{\circ} \mathrm{C}$ and assessed for emergence of actinobacteria colony every day. Actinobacteria-like strains were selected based on the colony morphology: solid density of colonies, growth inside the agar media, and steady border of the colonies [34]. The colonies were transferred from the primary plates to fresh MS plates. Pure cultures were obtained for all the colonies identified as actinobacteria on the primary plates. Several isolated strains were deposited in the Russian Collection of Agricultural Microorganisms (RCAM), St. Petersburg, Russia.

2.2. 16S rRNA Gene Sequencing and Phylogenetic Analysis. For isolation of total DNA, the strains were cultivated in $10 \mathrm{~mL}$ of TSB medium in shake flasks at $28^{\circ} \mathrm{C}$ for 3 days at $180 \mathrm{rpm}$. The total DNA was isolated with the salting out procedures as described in [34]. To identify the isolates, the 16S rRNA gene was amplified by PCR with the actinobacteria-specific primers: F-Act-235(CGC GGC CTA TCA GCT TGT TG) and R-Act-878(CCG TAC TCC CCA GGC GGG G) [35]. The PCR reaction was performed using the ScreenMix 5X PCR kit and included all the necessary components of PCR (high-performance Taq DNA polymerase, a mixture of deoxynucleoside triphosphates, $\mathrm{Mg}^{2+}$, PCR buffer, and dyes (Kat. PK041L, Evrogen, Russia. http:// www.evrogen.com). PCR was performed in a T-Gradient thermocycler (Biometra, Germany) in the volume of $25 \mu \mathrm{L}$. The PCR parameters were as follows: initial denaturation at $95^{\circ} \mathrm{C}$ for $5 \mathrm{~min}$, followed by 25 cycles of $95^{\circ} \mathrm{C}$ for $40 \mathrm{sec}$, $49-52^{\circ} \mathrm{C}$ for $25 \mathrm{sec}$, and $72^{\circ} \mathrm{C}$ for $110 \mathrm{sec}$, and final elongation at $72^{\circ} \mathrm{C}$ for $5 \mathrm{~min}$ [36].

The PCR products were purified using Cleanup Standard Column Extraction kit (Kat. BC022, Evrogen, Russia) and sequenced using actinobacteria-specific primers. The PCR product mixture with amplification primers was sent to the Syntol company (Moscow, Russia) for sequencing the PCR products with the Sanger method [37]. Forward and reverse sequences were assembled with Bioedit software (version 7.2.5). The obtained sequences were deposited in the GenBank with the following numbers: MH393589-MH393597 (Table 1)

For phylogenetic analysis, the sequences were aligned using MEGA software (version 7.0) [38]. The evolutionary history was inferred using the maximum parsimony method. Percentage of replicate trees, where the associated taxa clustered together in the bootstrap test (1000 replicates), is shown next to branches [39]. Bacterium of the species Bacillus licheniformis, often found in microbial communities of the various plants rhizosphere, was used as outgroup.

2.3. Cultivation and Extraction. The isolated strains were cultivated in $30 \mathrm{~mL}$ of production medium in $250 \mathrm{~mL}$ shake flasks with baffles for 7 days at $28^{\circ} \mathrm{C}$ at $180 \mathrm{rpm}$ shaking rate [34]. Three different liquid media were chosen to estimate primary antibiotic activity. These media are NL19 (soy flour $20 \mathrm{~g}$, D-mannitol-20 g, tap water $1 \mathrm{~L}$, and $\mathrm{pH} 7.2$ ), SG (glucose $20 \mathrm{~g}$, glycerol $10 \mathrm{~g}$, soytone $10 \mathrm{~g}, \mathrm{CaCO}_{3} 2 \mathrm{~g}, \mathrm{CoCl}_{2}$
$0.001 \mathrm{~g}, \mathrm{pH} 7.2$, distilled water $1 \mathrm{~L}$, and $\mathrm{pH} 7.2$ ), and SM17 medium (glucose $2 \mathrm{~g}$, glycerol $31.7 \mathrm{ml}$, soluble starch $2 \mathrm{~g}$, soy flower $5 \mathrm{~g}$, peptone $5 \mathrm{~g}$, yeast extract $5 \mathrm{~g}, \mathrm{NaCl} 5 \mathrm{~g}, \mathrm{CaCO}_{3} 2 \mathrm{~g}$, $\mathrm{pH}$ 6.4, tap water $1 \mathrm{~L}, \mathrm{pH} 7.2$ ).

The grown cultures were centrifuged at $3.000 \mathrm{~g}$ for $10 \mathrm{~min}$ to separate the biomass and cultural liquid. Then, secondary metabolites were extracted from the liquid culture with equal volume of ethyl acetate. To extract natural products from the biomass, we used $10 \mathrm{~mL}$ of acetonemethanol mixture (ratio $1: 1$ ). Extraction was performed during $1 \mathrm{~h}$ on a rotator at $100 \mathrm{rpm}$ at room temperature. The obtained crude extracts were evaporated in vacuo using the IKA RV-8 rotatory evaporator (IKA, Germany) at $40^{\circ} \mathrm{C}$ and dissolved at concentration $25 \mu \mathrm{g} / \mathrm{L}$ of methanol-DMSO mixture (ratio $1: 1$ ) [40].

\subsection{Assay of Antimicrobial Activity of Isolated Strain Extracts.} Antimicrobial effects of the extracted metabolites were tested using the spectrophotometry test in a microplate reader Infinite M200 (Tecan, Austria) at $610 \mathrm{~nm}$ wavelength. For the analysis, 96 well plates were used. $1 \mu \mathrm{L}$ of extract and $100 \mu \mathrm{L}$ of the test culture were applied to the spectrophotometer wells. Using the technique of serial dilutions, final concentration of extracts in the wells was ranged from $25 \mathrm{ug} / \mathrm{L}$ to $6.25 \mathrm{ug} / \mathrm{L}$. The analysis was carried out in two biological and four analytical replicates at $28^{\circ} \mathrm{C}$ (for yeasts) and $37^{\circ} \mathrm{C}$ (for bacteria). Antibiotics ceftriaxone, streptomycin, and nystatin were used as positive and negative controls. Data were normalized by (1) optical density of the sterile medium and (2) optical density of the growth of test cultures in standard conditions. In these wells, the solvent used for preparations of crude extracts (mixture of methanol and DMSO) was added in the same volume. Thus, optical density of the transparent medium was equated to absence of growth of test cultures and $-100 \%$ (minus means inhibition) of inhibition rate after 12-18 hours [41, 42].

Several bacterial and fungal test cultures, such as Bacillus subtilis ATCC 66337, Staphylococcus carnosus ATCC 51365, Escherichia coli ATCC25922, and Saccharomyces cerevisiae BY4742 were chosen to test antibiological properties. Test cultures were obtained from the Leibniz-Institute DSMZGerman Collection of Microorganisms and Cell Cultures (Braunschweig, Germany).

\section{Results}

3.1. Isolation and Phylogenetic Analysis of Actinobacteria Associated with Baikal Algae. A total of 9 strains of cultivable actinobacteria were isolated here using the selected approaches and media. BLAST analysis of nucleotide sequences aligned for the 16S rRNA gene revealed high similarity of strains between actinobacteria associated with D. baikalensis alga and sequences of actinobacteria strains that were previously deposited in the Genbank database (NCBI). All of the isolated strains were identified as bacteria related to phylum Actinobacteria (Table 1). It was revealed that 5 strains belonged to the genus Streptomyces sp. Also, one 
TABLE 1: Strains of actinobacteria isolated from D. baicalensis and similar ID sequences of microorganisms deposited in the GenBank, NCBI.

\begin{tabular}{|c|c|c|c|c|c|}
\hline No & Isolate & NCBI ID & $\begin{array}{l}\text { Similarity } \\
(\%)\end{array}$ & Close strains & Source, importance (if available) \\
\hline \multirow{3}{*}{1} & \multirow{3}{*}{$\begin{array}{l}\text { Nonomuraea sp. IB } \\
\text { 2015I9-2 }\end{array}$} & \multirow{3}{*}{ MH393597 } & 96 & $\begin{array}{l}\text { MF431313.1 Nonomuraea sp. } \\
\text { YIM C01536 }\end{array}$ & Genomic DNA isolated from cave, China \\
\hline & & & 96 & $\begin{array}{l}\text { KT004650.1 Nonomuraea sp. } \\
\text { HCI01 }\end{array}$ & Genomic DNA isolated from soil, China \\
\hline & & & 96 & $\begin{array}{l}\text { KC577161.1 Nonomuraea } \\
\text { maheshkhaliensis SB4 }\end{array}$ & Genomic DNA isolated from soil, Iran \\
\hline \multirow{3}{*}{2} & \multirow{3}{*}{$\begin{array}{l}\text { Micromonospora sp. IB } \\
\text { 2015I12-1 }\end{array}$} & \multirow{3}{*}{ MH393594 } & 100 & $\begin{array}{l}\text { MF769742.1 Micromonospora sp. } \\
\text { MK-8-15 }\end{array}$ & $\begin{array}{l}\text { Genomic DNA isolated from sea sediments, } \\
\text { China }\end{array}$ \\
\hline & & & 100 & $\begin{array}{c}\text { MF769739.1 Micromonospora sp. } \\
\text { MK-8-10 }\end{array}$ & $\begin{array}{c}\text { Genomic DNA isolated from sea sediments, } \\
\text { China }\end{array}$ \\
\hline & & & 100 & $\begin{array}{c}\text { KY858240.1 Micromonospora } \\
\text { chokoriensis } \mathrm{B} 032\end{array}$ & Genomic DNA isolated from sediments, USA \\
\hline \multirow{3}{*}{3} & \multirow{3}{*}{$\begin{array}{l}\text { Sacharopolyspora sp. IB } \\
\text { 2015I10-2 }\end{array}$} & \multirow{3}{*}{ МH393596 } & 99 & $\begin{array}{c}\text { MH027604.1 Saccharopolyspora } \\
\text { gregorii BM8-3 }\end{array}$ & Genomic DNA isolated from sea mud, China \\
\hline & & & 99 & $\begin{array}{c}\text { KY056170.1 Saccharopolyspora } \\
\text { gregorii DB34 }\end{array}$ & $\begin{array}{l}\text { Genomic DNA isolated from drug plants, } \\
\text { India }\end{array}$ \\
\hline & & & 99 & $\begin{array}{c}\text { KY015031.1 Saccharopolyspora } \\
\text { sp. WMMA1665 }\end{array}$ & $\begin{array}{c}\text { Genomic DNA isolated from sea sponges, } \\
\text { China }\end{array}$ \\
\hline \multirow{3}{*}{4} & \multirow{3}{*}{$\begin{array}{l}\text { Rhodococcus sp. IB } \\
\text { 2017D16-1 HS }\end{array}$} & \multirow{3}{*}{ МH393595 } & 98 & $\begin{array}{c}\text { KR817789.1 Rhodococcus sp. JSM } \\
147646\end{array}$ & Genomic DNA isolated from forest soil, China \\
\hline & & & 98 & DQ157923.1 Rhodococcus sp. R2 & Genomic DNA, USA \\
\hline & & & 98 & EU878299.1 Rhodococcus sp. 107 & $\begin{array}{c}\text { Genomic DNA isolated from sediments, } \\
\text { China }\end{array}$ \\
\hline \multirow{3}{*}{5} & \multirow{3}{*}{$\begin{array}{l}\text { Streptomyces sp. IB } \\
\text { 2015I8-1 }\end{array}$} & \multirow{3}{*}{ MH393593 } & 99 & $\begin{array}{c}\text { MH197381.1 Streptomyces } \\
\text { atratus } \text { HRT13 }\end{array}$ & $\begin{array}{c}\text { Genomic DNA isolated from rhizosphere of } \\
\text { Iris pseudacorus, Uzbekistan }\end{array}$ \\
\hline & & & 99 & $\begin{array}{c}\text { MF077025.1 Streptomyces atratus } \\
\text { 111-LNR5 }\end{array}$ & $\begin{array}{l}\text { Genomic DNA isolated from deep } \\
\text { rhizosphere desert plants, Korea }\end{array}$ \\
\hline & & & 98 & $\begin{array}{c}\text { MG923823.1 Streptomyces sp. } \\
\text { TPML13106 }\end{array}$ & $\begin{array}{l}\text { Genomic DNA isolated from xylos, Korea } \\
\text { Importance-fungal activity of extracts }\end{array}$ \\
\hline \multirow{3}{*}{6} & \multirow{3}{*}{$\begin{array}{l}\text { Streptomyces sp. IB } \\
\text { 2015I9-1 }\end{array}$} & \multirow{3}{*}{ MH393592 } & 95 & $\begin{array}{l}\text { KX928223.1 Streptomyces sp. } \\
\text { AC151_JC342 }\end{array}$ & $\begin{array}{l}\text { Strain isolated from skin of the bat } \\
\text { Corynorhinus townsendii, USA } \\
\text { Importance-fungal activity of extracts }\end{array}$ \\
\hline & & & 95 & $\begin{array}{c}\text { KY000530.1 Streptomyces sp. Kz- } \\
12\end{array}$ & Genomic DNA isolated from soil, India \\
\hline & & & 95 & $\begin{array}{c}\text { EU828543.1 Streptomyces scabiei } \\
208\end{array}$ & $\begin{array}{l}\text { Strain isolated from rhizosphere of plant, } \\
\text { China }\end{array}$ \\
\hline \multirow{3}{*}{7} & \multirow{3}{*}{$\begin{array}{l}\text { Streptomyces sp. IB } \\
\text { 2017D11-1 }\end{array}$} & \multirow{3}{*}{ MH393590 } & 99 & $\begin{array}{c}\text { KT443823.1 Streptomyces sp. N5- } \\
7\end{array}$ & Strain isolated from potato, China \\
\hline & & & 99 & $\begin{array}{c}\text { KY243996.1 Streptomyces } \\
\text { glauciniger UMBR } 0137\end{array}$ & $\begin{array}{l}\text { Strain isolated from rhizosphere of mangrove } \\
\text { forest soil, China } \\
\text { Importance-fungal activity of extracts }\end{array}$ \\
\hline & & & 99 & $\begin{array}{l}\text { GQ357946.1 Streptomyces sp. } \\
\text { HaNXJ11 }\end{array}$ & Strain isolated from soil, China \\
\hline \multirow{3}{*}{8} & \multirow{3}{*}{$\begin{array}{l}\text { Streptomyces sp. IB } \\
\text { 2017D11-2 }\end{array}$} & \multirow{3}{*}{ MH393591 } & 96 & $\begin{array}{l}\text { EU910871.1 Streptomyces sp. XJ } \\
11062\end{array}$ & $\begin{array}{l}\text { Strain isolated from soil, China. } \\
\text { Importance-halophilic strain }\end{array}$ \\
\hline & & & 95 & $\begin{array}{l}\text { LN615186.1Streptomyces sp. } \\
\text { MC12s29 }\end{array}$ & $\begin{array}{l}\text { Strain isolated from Roman's burial (etruscan } \\
\text { burial), Spain }\end{array}$ \\
\hline & & & 95 & $\begin{array}{l}\text { KU323817.1 Streptomyces sp. } \\
\text { YC504 }\end{array}$ & Genomic DNA isolated from water, Turkey \\
\hline \multirow{3}{*}{9} & \multirow{3}{*}{$\begin{array}{l}\text { Streptomyces sp. IB } \\
\text { 2015I12-2 }\end{array}$} & \multirow{3}{*}{ MH393589 } & 99 & $\begin{array}{l}\text { MG711818.1 Streptomyces sp. } \\
\text { KIB } 015\end{array}$ & $\begin{array}{l}\text { Strain isolated from plant Panax Notoginseng, } \\
\text { China. } \\
\text { Importance-producer of Labdanmycin A } \\
\text { and B }\end{array}$ \\
\hline & & & 99 & $\begin{array}{c}\text { KX928338.1 Streptomyces sp. } \\
\text { AC284_FS475 }\end{array}$ & Importance-fungal activity of extracts \\
\hline & & & 99 & $\begin{array}{c}\text { KU324437.1 Streptomyces sp. } \\
\text { RJA4055 }\end{array}$ & $\begin{array}{l}\text { Strain isolated from excrement of earthworms } \\
\text { that live in sewage treatment plants, China }\end{array}$ \\
\hline
\end{tabular}


representative per each of the following genera was identified as Sacharopolyspora sp., Micromonospora sp., Rhodococcus sp., and Nonomurea sp.

Based on comparison of the nucleotide sequences of $16 \mathrm{~S}$ rRNA gene of isolated strains aligned with the sequences of actinobacteria deposited in the Genbank (NCBI), we show that the isolated strains form tight separate clades with representatives of similar species. Separate branches of each genus are presented in Figures S3-S6. It is shown that the isolated strains related to the genus Streptomyces sp., Micromonospora sp., and Rhodococcus sp. do not form strict, independent, or distant clades with strains or genetic material previously found in soil or water substances, respectively.

Analysis of Nonomuraea sp. strains showed that the strain isolated in this study forms a clade with other representatives isolated from water sources (Figure 1). Other clades are quite mixed and contain both soil and water representatives. It should be noted that, as of June 2020, no nucleotide sequences belonging to the strains isolated from algae of Lake Baikal ecosystem were deposited into the NCBI system. Thus, our study is the first to mention this genus representative in the ecosystem of Lake Baikal and its microbial-phytobenthic communities. A similar case was also noted for the isolated strain of the genus Saccharopolyspora sp. (Figure S6). However, in contrary to the above Nonomuraea sp. representatives, the NCBI system contains one nucleotide sequence for actinobacteria of this genus isolated from alga Nostoc sp. Like in case of Nonomuraea sp., the present paper is the first to mention the actinobacteria related to the genus Saccharopolyspora sp. in Lake Baikal ecosystem.

3.2. Analysis of Biological Activity of Isolated Strains. The materials describing the activity of the extracts of actinobacteria strains cultivated in different nutrient media against Gram-positive bacteria are presented in Figures 2-4. Antimicrobial activity of crude extracts against growth of Staphylococcus carnosus at $25 \mathrm{ug} / \mathrm{L}$ concentration was observed in case of cell-free liquid culture extracts (Figure 2) and cellular biomass (Figure 3) of strains Micromonospora sp. IB 2015I12-1, Streptomyces sp. IB 2015I12-2, Streptomyces sp. IB 2015I9-1, and rare strain Nonomuraea sp. IB 2015I9-2. Also, extract obtained from the cellular biomass of the strain Streptomyces sp. IB 2015I8-1 cultivated in SG media was characterized by high inhibition properties.

Extract of cellular biomass of the strain Streptomyces sp. IB 2015I9-1 did not show pronounced antagonistic activity against St. carnosusin at all tested concentrations (6.25-25 ug/L). However, we observed activity of crude extract of this strain when it was cultivated in SM17 medium. The observed activity can be compared with that of streptomycin and ceftriaxone antibiotics in the same concentrations (Figure S7).

Crude extract of cell-free liquid culture of the strain Nonomuraea sp. IB 2015I9-2 was active against St. carnosus culture when cultivated on all media at all concentrations.
However, the crude extract of cellular biomass did not show antibiotic activity under the tested conditions (Figure S8). In case of the strain Micromonospora sp. IB 2015I12-1, the highest antibiotic activity was observed in extract of the cellfree liquid culture obtained by the strain cultivation in NL19 medium. Under these conditions, growth of $82 \pm 8.9 \%$ cells of St. carnosus was inhibited. The decrease in concentration to $12.5 \mathrm{ug} / \mathrm{L}$ and $6.25 \mathrm{ug} / \mathrm{L}$ led to suppression of St. carnosus growth to $53-59 \%$ (Figure 4).

Bacillus subtilis was another culture tested in the current study. The most expressed antimicrobial activity against growth of B. subtilis at concentration $25 \mathrm{ug} / \mathrm{L}$ was revealed for crude extracts of the cell-free liquid culture of strains Micromonospora sp. IB 2015I12-1, Streptomyces sp. IB 2015I9-1, and Streptomyces sp. IB 2017D11-2. At the same time, the activity of the extracts obtained from the cellular biomass of the same strains was less (Figures S9 and S10). Among the extracts obtained from cellular biomass, the highest activity was detected for the strains Sacharopolyspora sp. IB 2015I10-2, Streptomyces sp. IB 2015I8-1, and Streptomyces sp. IB 2017D11-1.

Figure 4 presents the materials evaluating activity of the strain Micromonospora sp. IB 2015I12-1. It was shown that crude extracts of cellular biomass had weak antibiotic activity, whereas the optimal medium for extracellular synthesis of antibiotics was NL19 medium. At the same time, extracts obtained from the cell-free liquid culture of this strain grown in SM17 and SG media contributed to growth stimulation of the model test culture.

The materials describing the activity of the isolated actinobacteria extracts against Gram-negative bacteria are presented in Figures S11-S14 (supplementary). Crude extracts of the cell-free liquid culture (Figure S11) and cellular biomass (Figure S12) prepared at a concentration of $25 \mathrm{ug} / \mathrm{L}$, obtained from several isolated strains (Streptomyces sp. IB 2015I9-1, Micromonospora sp. IB 2015I12-1, Streptomyces sp. IB 2015I12-2, and Streptomyces sp. IB 2015D11-2), inhibited the growth of Escherichia coli.

The materials describing the activity of the extracts of isolated actinobacteria against yeasts $S$. cerevisiae are shown in Figures S15-S18 (Supplementary). Only two isolated strains (Streptomyces sp. IB 2015I9-1 and Nonomuraea sp. IB 2015I9-2) were characterized by the pronounced activity against growth of saccharomyces (Figures S15 and S16). In case of the strain Streptomyces sp. IB 2015I9-1, extracts obtained from the cell-free liquid cultures of this strain during cultivation in SM17 medium were active against $S$. cerevisae growth. The activity of this strain-related extract was comparable with nystatin activity. Extracts of the cellular biomass did not show visible inhibitory activity (Figure S17 and S18). Another strain Nonomuraea sp. IB2015I9-2 was characterized by a weak antibiotic activity. The inhibition rate of the cell-free liquid culture extracts was less than $50 \%$. The cellular biomass extract obtained by strain cultivation in SM17 nutrient medium showed an inhibition rate of $58 \pm 7.3 \%$ against tested yeast. Crude extracts obtained by strain cultivation in another tested nutrient media caused growth stimulation of $S$. cerevisae. 


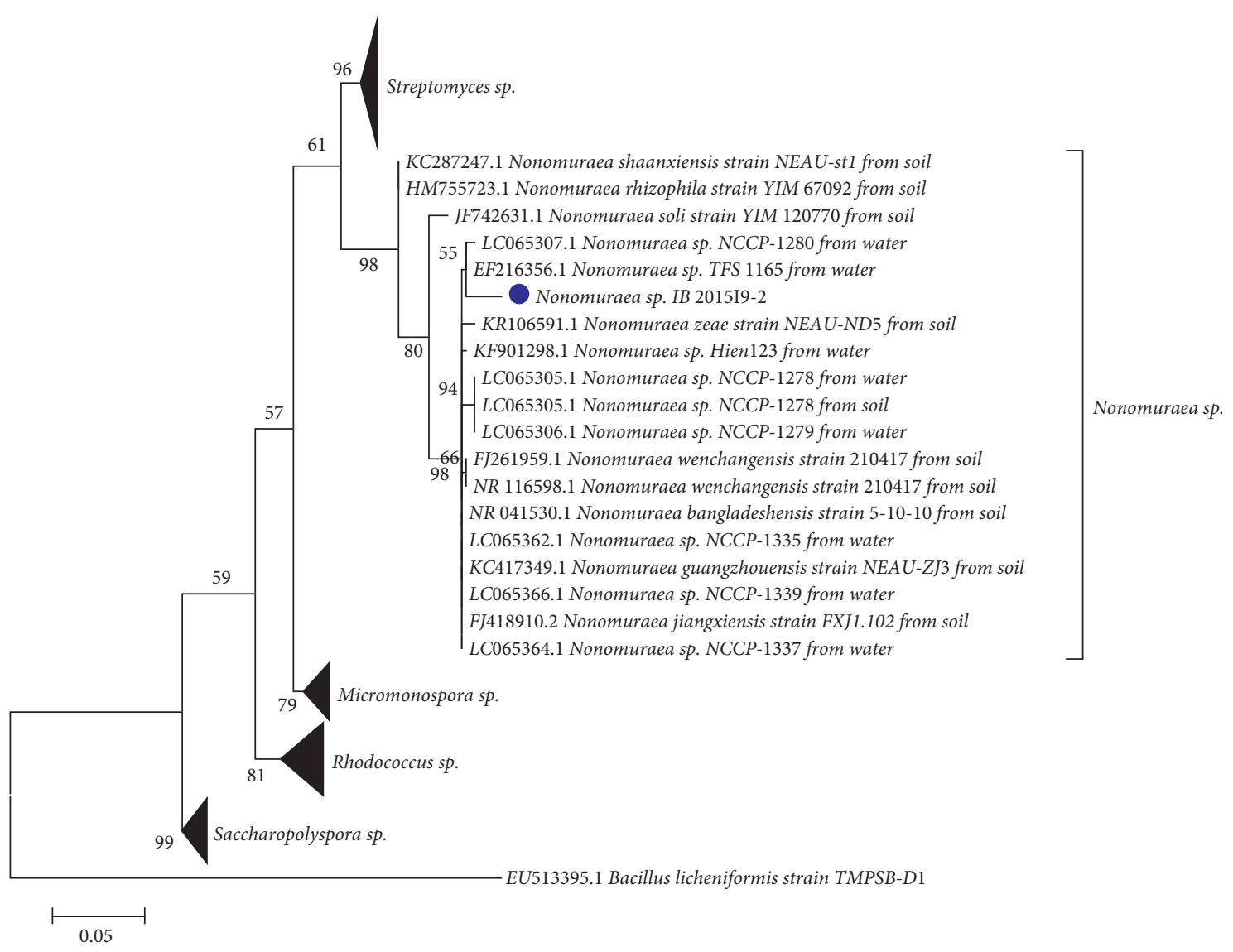

Figure 1: Phylogenetic tree of the genus Nonomuraea sp. constructed using the maximum likelihood method based on the comparison of the nucleotide sequences of 16S rRNA gene deposited in GenBank. Note.- Bootstrap-1000. The analysis involves 21 sequences, and the length of nucleotides is 411 . The tree includes 10 strains of bacteria isolated from soil (marked "from soil"); 8 strains of bacteria isolated from water of different reservoirs (marked "from water"); and 1 strain isolated in the course of this study. The analysis was carried out in MEGA7 program. Outgroup is presented by B. licheniformis.

\section{Discussion}

During this study, we first time isolated several strains of cultivable actinobacteria from Baikal endemic alga D. baicalensis. We estimated their similarity with other actinobacteria and performed initial description of crude extracts antibiotic activity of bacteria cultivated in different nutrient media. According to the materials obtained in this study, we could preliminarily conclude that diversity of cultivable actinobacteria and rare genera isolated from $D$. baicalensis is comparable to that of cultivable actinobacteria that we previously isolated from the pollen of a pine species growing on the shore of the lake [29]. At the same time, according to published data, the diversity of rare genera of cultivable actinobacteria isolated here from the alga exceeds the cultivable actinobacteria diversity described for Lake Baikal macroinvertebrates $[32,43]$, water $[44,45]$, or sediments $[46$, 47] (Figure 5). The increased diversity of rare genera of actinobacteria in plant sources could be preliminarily explained by the chemical composition and availability of nutrients (vitamins or fatty acids) produced by plants or algae. During the analysis of nutrient media used for isolation of rare strains, we observed that specific media often include vitamins, plant extracts, and soil or humic substances [48]. Thus, the plant material seems to be "natural trap" for accumulation and attraction of rare actinobacteria species. Also, due to high organized enzymatic system of cellulose destruction in actinobacteria, this diversity could be explained by the possibility to hydrolysis of cellulosecontaining cell wall of plants and algae and consumption of this source of carbon [49].

Similar to other studies conducted in the Baikal and nonBaikal regions $[50,51]$, the genus Streptomyces was found as the most common and dominant one $[52,53]$. According to the phylogenetic analysis performed, representatives of Baikal actinobacteria do not form separate clades and they are highly similar to other representatives of actinobacteria related to this genus. This study identified representatives of the genera Nonomuraea sp. and Saccharopolyspora sp. in the ecosystem of Lake Baikal for the first time.

Also, a strain related to the genus Nonomuraea sp. was first isolated from freshwater algae. In case of the isolated strain Saccharopolyspora sp., only one nucleotide sequence is registered in the NCBI system as an algal-associated 


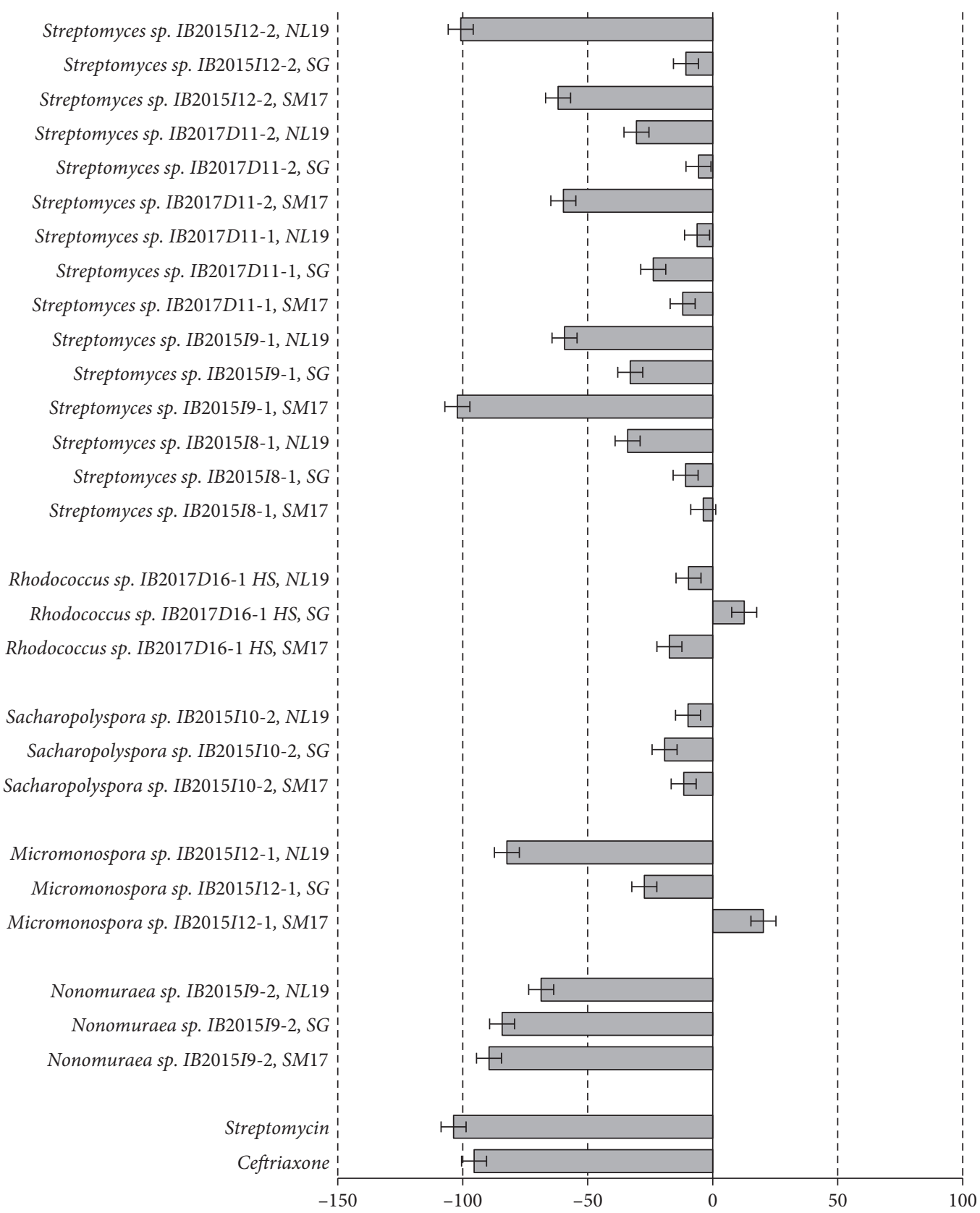

FIgURe 2: Antibacterial activity of crude extracts obtained from the cell-free liquid culture of the isolated strains at concentration $25 \mu \mathrm{g} / \mathrm{L}$ against St. carnosus. Note. “-": inhibition rate, in \%, mean \pm SD.

microbial community of Nostoc sp. Thus, our study is the first to mention about actinobacteria of the genus Nonomuraea sp. and Saccharopolyspora sp. living in the ecosystem of Lake Baikal.

The assessment of the role of some microorganisms and actinobacteria in plant communities is well known and has already been mentioned in the introduction chapter and in [54-57]. A lot of studies postulate the estimation of microbial diversity, associated with algae and other water-related organisms [58-60]. However, only a few studies are involved with assessment of relationship between algae and actinobacteria. As described in Zenova et al. [61], algobacterial communities represent a highly productive system.
In this system, blue-green algae are the main producers of organic material. The latter can be used as a source of carbon and energy in heterotrophic microorganisms related to the community. Entering into the associations with bacteria, the blue-green algae are involved in food chain formation. Associations of actinobacteria with green algae are called actinolichen, where actinobacteria participate in the system stabilization and enhance the photosynthetic activity of algae [61]. Also, other studies have shown the stimulation of Oscillatoria terebriformis growth in the associated culture with the streptomyces strain. In addition, increased nitrogen fixation by Anabaena variabilis and higher photosynthetic activity of $O$. terebriformis in streptomyces-associated 


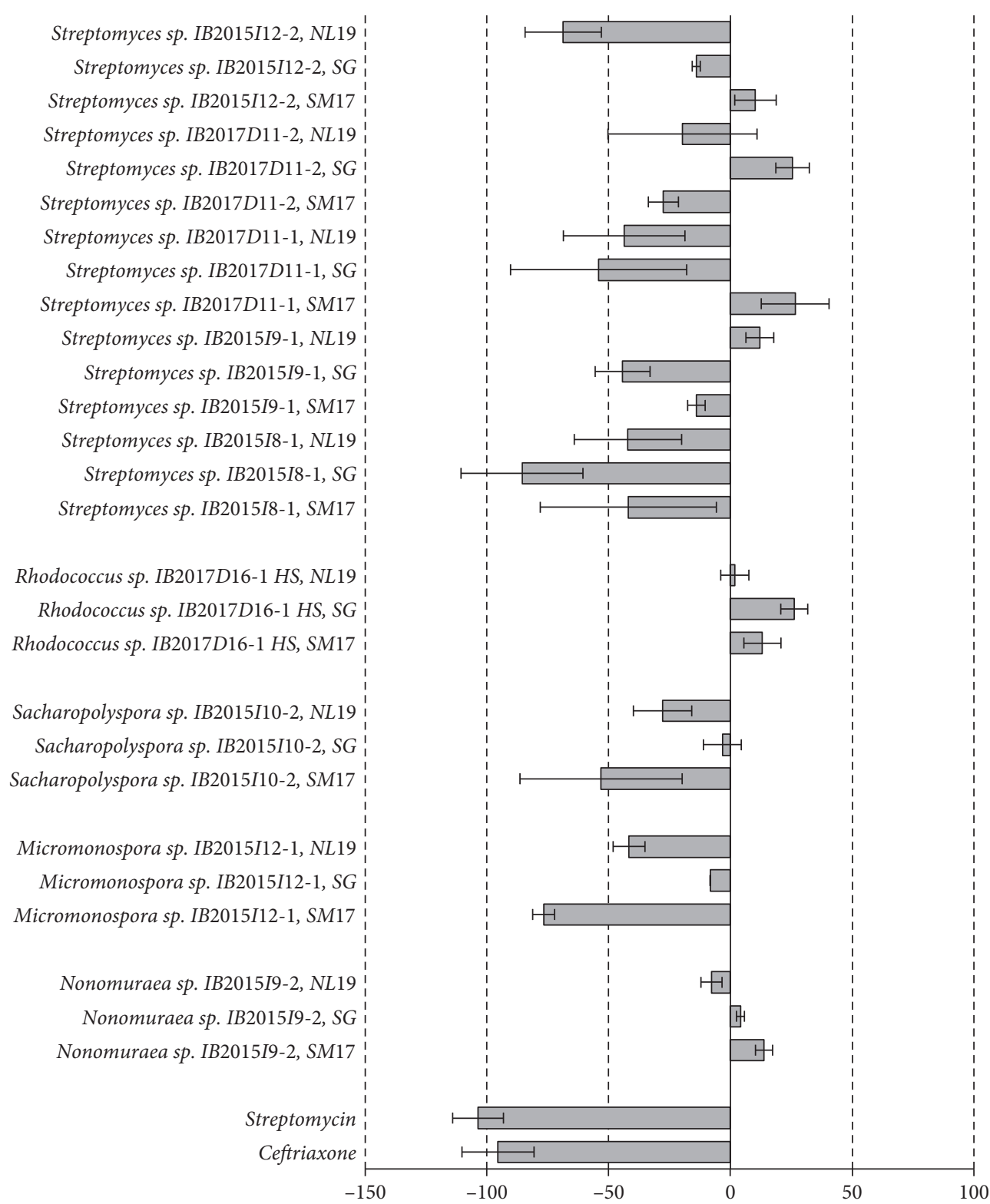

Figure 3: Antibacterial activity of crude extracts obtained from the cellular biomass of the isolated strains at a concentration of $25 \mu \mathrm{g} / \mathrm{L}$ against St. carnosus. Note. "-": inhibition rate, in \%, mean \pm SD.

culture was recorded [62]. Michel et al. [63] showed that some algae and actinobacteria are closely related in their evolution. For example, terminal stages of cellulose and hemicellulose biosynthesis of the alga Ectocarpus siliculosus were inherited from actinobacteria to red alga by horizontal gene transfer [63].

In addition to assessment of cultivated actinobacteria diversity, in this study, we demonstrated that the strains isolated from endemic algae exhibit pronounced antibiotic activity and high content of active strains, including rare strains. From the data obtained, it was established that 8 out of 9 isolated strains showed high activity with the rate of growth inhibition more than 70\% (Figure 6). Only one strain, Rhodococcus sp. IB2015I 16-1HS, was not active under the tested conditions. This could be explained by the strain ecology and requirements of this strain to specific media, including oil, paraffin waxes, or other aromatic hydrocarbons $[64,65]$. The main revealed antimicrobial activity against the chosen test cultures was demonstrated by the strains Micromonospora sp. IB 2015I12-1, Streptomyces sp. IB 2015I8-1, and Streptomyces sp. IB 2015I9-1.

The differences observed in the activity of extracts from cell-free liquid culture and from cellular biomass within one strain can be explained by peculiarities of synthesis of natural compounds, their nature, and functional significance [34]. Also, the ability to synthesize secondary metabolites directly depends on composition of the nutrient medium used for cultivation.

As we mentioned before, microorganisms of antient and specific ecosystems and extremophilic communities are the new sources of novel antibiotics and natural compounds. Among the studies dealing with algae, a well-known example 


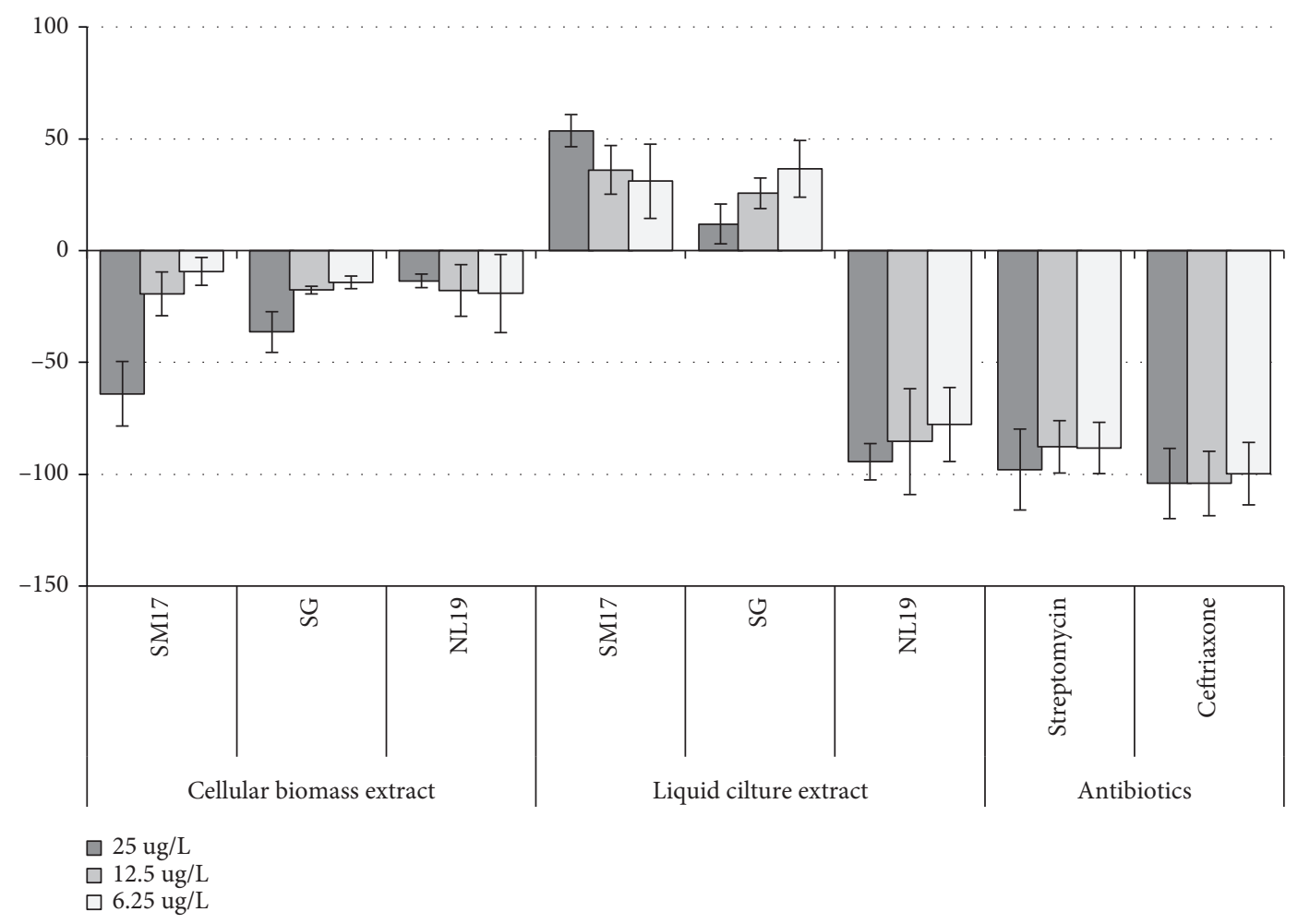

Figure 4: Antibacterial activity of crude extracts of strain Micromonospora sp. IB 2015I12-1 obtained after cultivation in different nutrient media against B. subtilis. Note. “-": inhibition rate, in \%, mean \pm SD.

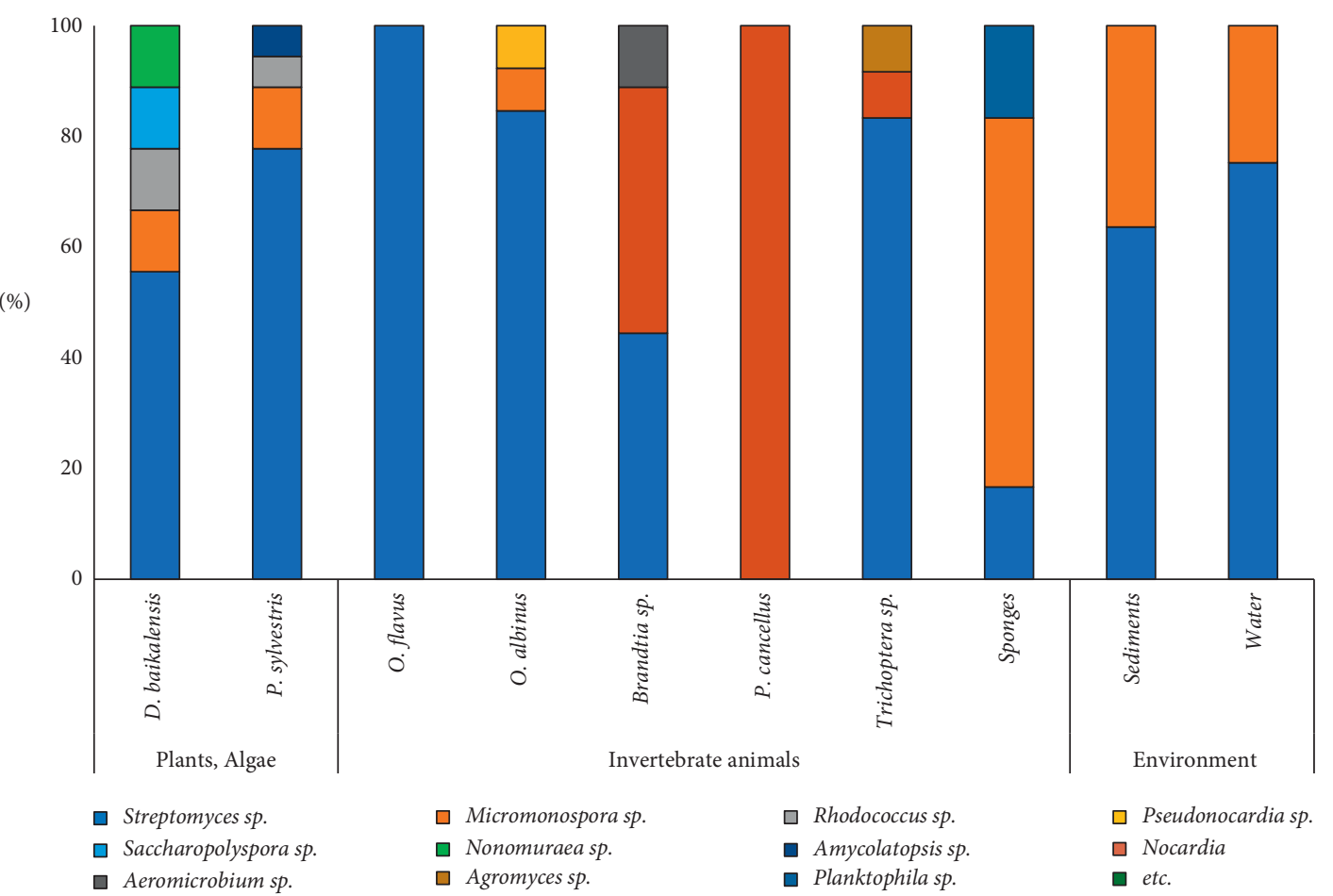

FIGURE 5: Distribution of cultivable actinobacteria isolated from different ecological groups of organisms or environment of Lake Baikal ecosystem.

is actinobacteria related to Nocardia sp. ALAA 2000, which was isolated from the brown alga Laurenica spectabilis. The studies performed by El-Gendy et al. [66] demonstrated that this bacterial strain produces 4 antibiotics, including chrysophanol 8-methyl ether, asphodelin, justicidin B, and ayamycin. These antibiotics have pronounced antimicrobial 


\begin{tabular}{|c|c|c|c|c|c|c|c|c|c|}
\hline \multirow{3}{*}{ Strain } & \multirow{3}{*}{ Media } & \multicolumn{8}{|c|}{ Test culture } \\
\hline & & \multicolumn{2}{|c|}{ B. subtilis } & \multicolumn{2}{|c|}{ S. carnosus } & \multicolumn{2}{|c|}{ E. coli } & \multicolumn{2}{|c|}{ S. cerevisae } \\
\hline & & Liq.cult. & Cell.biom. & Liq.cult. & Cell.biom. & Liq.cult. & Cell.biom. & Liq.cult. & Cell.biom. \\
\hline \multirow{3}{*}{$\begin{array}{l}\text { Nonomuraea sp. } \\
\text { IB2015I9-2 }\end{array}$} & \multirow{3}{*}{$\begin{array}{c}\text { SM17 } \\
\text { SG } \\
\text { NL19 }\end{array}$} & & & -89 & & & & & \\
\hline & & & & -84 & & & & & \\
\hline & & & & -69 & & & & & \\
\hline \multirow{3}{*}{$\begin{array}{l}\text { Micromonospora sp. } \\
\text { IB 2015I12-1 }\end{array}$} & \multirow{3}{*}{$\begin{array}{c}\text { SM17 } \\
\text { SG } \\
\text { NL19 }\end{array}$} & & & & -77 & & -81 & & \\
\hline & & & & & & -77 & & & \\
\hline & & -94 & & -82 & & -73 & -97 & & \\
\hline \multirow{3}{*}{$\begin{array}{l}\text { Sacharopolyspora sp. } \\
\text { IB2015I10-2 }\end{array}$} & \multirow{3}{*}{$\begin{array}{c}\text { SM17 } \\
\text { SG } \\
\text { NL19 }\end{array}$} & & -85 & & & & & & \\
\hline & & & -78 & & & & & & \\
\hline & & & & & & & & & \\
\hline \multirow{3}{*}{$\begin{array}{l}\text { Rhodococcus sp. } \\
\text { IB2017D16-1 HS }\end{array}$} & \multirow{3}{*}{$\begin{array}{c}\text { SM17 } \\
\text { SG } \\
\text { NL19 }\end{array}$} & & & & & & & & \\
\hline & & & & & & & & & \\
\hline & & & & & & & & & \\
\hline \multirow{3}{*}{$\begin{array}{l}\text { Streptomyces sp. } \\
\text { IB2015I8-1 }\end{array}$} & \multirow{3}{*}{$\begin{array}{c}\text { SM17 } \\
\text { SG } \\
\text { NL19 }\end{array}$} & & & & & & & & \\
\hline & & & -90 & & $\overline{-86}$ & & & & \\
\hline & & & & & & & & & \\
\hline \multirow{3}{*}{$\begin{array}{l}\text { Streptomyces sp. } \\
\text { IB2015I9-1 }\end{array}$} & \multirow{3}{*}{$\begin{array}{c}\text { SM17 } \\
\text { SG } \\
\text { NL19 }\end{array}$} & -100 & & -100 & & $\overline{-100}$ & & -89 & \\
\hline & & & & & & & -100 & & \\
\hline & & -72 & & & & -82 & -85 & & \\
\hline \multirow{3}{*}{$\begin{array}{l}\text { Streptomyces sp. } \\
\text { IB2017D11-1 }\end{array}$} & \multirow{3}{*}{$\begin{array}{c}\text { SM17 } \\
\text { SG } \\
\text { NL19 }\end{array}$} & & & & & & & & \\
\hline & & & $\overline{-71}$ & & & & & & \\
\hline & & & $\overline{-81}$ & & & & & & \\
\hline \multirow{3}{*}{$\begin{array}{l}\text { Streptomyces sp. } \\
\text { IB2017D11-2 }\end{array}$} & \multirow{3}{*}{$\begin{array}{c}\text { SM17 } \\
\text { SG } \\
\text { NL19 }\end{array}$} & & & & & -86 & & & \\
\hline & & & & & & & & & \\
\hline & & -100 & & & & & & & \\
\hline \multirow{3}{*}{$\begin{array}{l}\text { Streptomyces sp. } \\
\text { IB2015I12-2 }\end{array}$} & \multirow{3}{*}{$\begin{array}{c}\text { SM17 } \\
\text { SG } \\
\text { NL19 }\end{array}$} & & & & & & & & \\
\hline & & & & & & & & & \\
\hline & & & & -100 & & $\overline{-94}$ & & & \\
\hline
\end{tabular}

Figure 6: The activity of the strains isolated from endemic alga D. baicalensis. Note. The table shows the inhibition activity of strains in excess of $70 \%$.

activity against both Gram-positive and Gram-negative bacteria and against fungi, at a minimum inhibiting concentration of $0.1-10 \mu \mathrm{g} / \mathrm{ml}$ [66].

\section{Conclusion}

During the performed study, we first time isolated several strains of cultivable actinobacteria from Baikal endemic alga D. baicalensis. We estimated their similarity with other actinobacteria and performed initial description of crude extracts in terms of antibiotic activity of bacteria cultivated in different nutrient media. Several strains of rare actinobacteria species were firstly found in the ecosystem of Lake Baikal and/or were shown to be involved in algal associations. The strains capable of inhibiting growth and development of bacteria and fungi are of great biotechnological and biopharmaceutical significance. Rare and active strains associated with the endemic alga $D$. baicalensis could be the promising sources for biomedical and biotechnological developments and discovery of new natural compounds.

\section{Data Availability}

The sequence data used to support the findings of this study have been deposited in the NCBI Genbank repository (https://www.ncbi.nlm.nih.gov/genbank/). The Russian text of reports is presented in the state information system for the registration of research, experiments, and technological studies for civilian purposes (https://rosrid.ru).

\section{Conflicts of Interest}

The authors declare that they have no conflicts of interest.

\section{Acknowledgments}

The study was carried out with the main financial support of Russian Science Foundation, grant 18-74-00018, with partial financial support from the Russian Foundation for Basic Research, grants 18-29-05051 and 18-34-00294, and the Ministry of Education and Science of Russian Federation, grant FZZE-2020-0026. 


\section{Supplementary Materials}

Figure S1: microphotographs of several algae species inhabiting Lake Baikal: 1, Mallomonas sp.; 2, Hannaea arcus; 3, Gymnodinium coeruleum; 4, Ceratium hirundinella; 5, Synedra acus; 6, Cyclotella minuta. Figure S2: endemic alga $D$. baicalensis. Figure S3: phylogenetic tree of the genus Streptomyces sp. constructed using the maximum likelihood method based on comparison of the nucleotide sequences of $16 \mathrm{~S}$ rRNA gene deposited in Genbank. Figure S4: phylogenetic tree of the genus Rhodococcus sp. constructed using the maximum likelihood method based on comparison of the nucleotide sequences of 16S rRNA gene deposited in Genbank. Figure S5: phylogenetic tree of the genus Micromonospora sp. constructed using the maximum likelihood method based on comparison of the nucleotide sequences of 16S rRNA gene deposited in Genbank. Figure S6: Phylogenetic tree of the genus Saccharopolyspora sp. constructed using the maximum likelihood method based on comparison of the nucleotide sequences of 16S rRNA gene deposited in Genbank. Figure S7: antibacterial activity of crude extracts of the strain Streptomyces sp. IB 2015I9-1 obtained after cultivation in different nutrient media against St. carnosus. Figure S8: antibacterial activity of crude extracts of the strain Nonomuraea sp. IB 2015I9-2 obtained after cultivation in different nutrient media against St. carnosus. Figure S9: antibacterial activity of crude extracts obtained from the cell-free liquid culture of the isolated strains at a concentration $25 \mu \mathrm{g} / \mathrm{L}$ against B. subtilis. Figure S10: antibacterial activity of crude extracts obtained from the cellular biomass of the isolated strains at a concentration $25 \mu \mathrm{g} / \mathrm{L}$ against B. subtilis. Figure S11: antibacterial activity of crude extracts obtained from the cell-free liquid culture of the isolated strains at a concentration $25 \mu \mathrm{g} / \mathrm{L}$ against E. coli. Figure S12: antibacterial activity of crude extracts obtained from the cellular biomass of the isolated strains at a concentration $25 \mu \mathrm{g} / \mathrm{L}$ against $E$. coli. Figure S13: antibacterial activity of crude extracts of Streptomyces sp. IB 2015I9-1 obtained after cultivation in different nutrient media against E. coli. Figure S14: antibacterial activity of crude extracts of Micromonospora sp. IB 2015I12-1 obtained after cultivation in different nutrient media against E. coli. Figure S15: antifungal activity of crude extracts obtained from the cell-free liquid culture of the isolated strains at a concentration $25 \mu \mathrm{g} / \mathrm{L}$ against $S$. cerevisiae. Figure S16: antifungal activity of crude extracts obtained from the cellular biomass of the isolated strains at a concentration $25 \mathrm{ug} / \mathrm{L}$ against $S$. cerevisiae. Figure S17: antifungal activity of crude extracts of Streptomyces sp. IB 2015I9-1 obtained after cultivation in different nutrient media against $S$. cerevisiae. Figure S18: antifungal activity of crude extracts of Nonomuraea sp. IB 2015I9-2 obtained after cultivation in different nutrient media against $S$. cerevisiae. (Supplementary Materials)

\section{References}

[1] C. L. Ventola, "The antibiotic resistance crisis: part 1: causes and threats," Pharmacology \& Therapeutics, vol. 40, no. 4, pp. 277-283, 2015.

[2] H. Jenke-Kodama and E. Dittmann, "Evolution of metabolic diversity: insights from microbial polyketide synthases," Phytochemistry, vol. 70, no. 15-16, pp. 1858-1866, 2009.

[3] C. Willyard, "The drug-resistant bacteria that pose the greatest health threats," Nature, vol. 543, no. 7643, p. 15, 2017.

[4] K. Tiwari and R. K. Gupta, "Rare actinomycetes: a potential storehouse for novel antibiotics," Critical Reviews in Biotechnology, vol. 32, no. 2, pp. 108-132, 2012.

[5] M. V. Gupta, S. E. Hampton, L. R. Izmest'eva, E. A. Silow, E. V. Peshkova, and B. K. Pavlov, "Climate change and the world's "sacred sea"-Lake Baikal, Siberia," BioScience, vol. 59, no. 5, pp. 405-417, 2009.

[6] O. A. Timoshkin, Index of Animal Species Inhabiting Lake Baikal and its Catchment Area, Nauka, Novosibirsk, Russia, in Russian, 2001.

[7] F. Darchambeau, H. Sarmento, and J.-P. Descy, "Primary production in a tropical large lake: the role of phytoplankton composition," Science of the Total Environment, vol. 473-474, pp. 178-188, 2014.

[8] L. G. Korneva and N. M. Mineeva, "Phytoplankton composition and pigment concentrations as indicators of water quality in the Rybinsk reservoir," The First International Lake Ladoga Symposium, vol. 322, pp. 255-259, 1996.

[9] R. O. Gutwinsky, Pionowen rozedleniu Glanow Jezera Baikalskiego, Kosmos, Lviv, Ukraine, 1890.

[10] S. M. Wislouch, "Beiträge zur Diatomeenflora von Asien. II. Untersuchungen über die Diatomeen des Baikalsees," Berichte der Deutschen Botanischen Gesellschaft, vol. 42, pp. 1-173, 1924.

[11] B. V. Skvortsov and K. I. Meyer, "A contribution to the diatoms of Baikal lake," in Proceedings of the Sungaree River Biological Station, vol. 1, pp. 1-55, 1928.

[12] K. I. Meyer, "Introduction to Lake Baikal algale flora," Bulletin Moscow Society of Naturalists, vol. 39, no. 3-4, pp. 179-392, 1930.

[13] A. P. Skabichevsky, "Addressing biology of Melosira baicalensis," Russian Hydribiological Journal, vol. 8, no. 4-5, pp. 93-113, 1929.

[14] V. N. Yasnitsky, "Results of Baikal plankton observations in studies of biological station in 1926-1928," in Proceedings of Biological and Geographical Research at Irkutsk State University, vol. 4, no. 4, pp. 191-238, 1930, in Russian.

[15] V. N. Yasnitsky and A. P. Skabichevsky, "Baikal phytoplankton," in Proceedings of the Baikal Limnological Station, vol. 15, pp. 212-261, 1957.

[16] O. M. Kozhova, "Horizontal distribution of plankton algae in Lake Baikal," News East Branches of AS USSR, vol. 4, no. 5, pp. 226-233, 1959.

[17] O. M. Kozhova, "Under-ice blooming of Lake Baikal," Botanicheskii Zhurnal, vol. 44, no. 7, pp. 1001-1004, 1959.

[18] N. L. Antipova, "Seasonal and annual changes in Lake Baikal phytoplankton," Proc. of Lymn. Inst of SB AS USSR, vol. 2, pp. 2-28, 1963.

[19] N. L. Antipova, "About variations in count of melosira species in plankton of Lake Baikal," All Union Hydrob Society, vol. 13, pp. $235-241,1963$.

[20] L. A. Izhboldina, Atlas and Determinant of Benthos Algae and Periphyton of Lake Baikal (Mayo-and Macrophytes) with Brief 
Essays on Their Ecology, Nauka-Centre, Novosibirsk, Russia, 2007.

[21] S. E. Hampton, L. R. Izmest'eva, M. V. Moore, S. L. Katz, and B. Dennis, "Sixty years of environmental change in the world's largest freshwater lake-lake Baikal, Siberia," Global Change Biology, vol. 14, no. 8, pp. 1947-1958, 2008.

[22] M. A. Silow, "Monitoring: safeguarding the world's largest lake," Nature, vol. 538, no. 7623, p. 41, 2016.

[23] P. Zhao, Y. Xue, W. Gao et al., "Actinobacteria-derived peptide antibiotics since 2000," Peptides, vol. 103, pp. 48-59.

[24] J. LiBai, F. Mohammadipanah, and J. Hamedi, Biology and Biotechnology of Actinobacteria, Springer, Berlin, Germany, 2017.

[25] M. Stadler and P. Dersch, How to Overcome the Antibiotic Crisis, Springer International, Berlin, Germany, 2017.

[26] A. I. Netrusov and I. B. Kotova, Microbiology, Akademiya, Moscow, Russia, 2007.

[27] V. V. Lysak, Microbiology: Study Guide, BSU, Muncie, Indiana, 2007.

[28] S. Karojet, S. Kunz, and J. T. van Dongen, "Microbacterium yannicii sp. nov., isolated from Arabidopsis thaliana roots," International Journal of Systematic and Evolutionary Microbiology, vol. 62, no. Pt_4, pp. 822-826, 2012.

[29] D. V. Axenov-Gribanov, I. V. Voytsekhovskaya, Y. V. Rebets et al., "Actinobacteria possessing antimicrobial and antioxidant activities isolated from the pollen of Scots pine (Pinus sylvestris) grown on the Baikal shore," Antonie Van Leeuwenhoek, vol. 109, no. 10, pp. 1307-1322.

[30] V. S. Vishnyakov, O. A. Timoshkin, L. A. Izhboldina, E. A. Volkova, and E. P. Zaytseva, "A taxonomic list of macroalgae in the near-shore zone of Bol'shye Koty and Listvenichny Bays (Southern Baikal)," The Bulletin of Irkutsk State University, vol. 5, pp. 147-159, 2012.

[31] M. Kozhov, Lake Baikal and its Life, vol. 11, Springer Science Business Media, Berlin, Germany, 2013.

[32] D. Axenov-Gribanov, Y. Rebets, B. Tokovenko, I. Voytsekhovskaya, M. Timofeyev, and A. Luzhetskyy, "The isolation and characterization of actinobacteria from dominant benthic macroinvertebrates endemic to Lake Baikal," Folia Microbiologica, vol. 61, no. 2, pp. 159-168, 2016.

[33] M. Girão, I. Ribeiro, T. Ribeiro et al., "Actinobacteria isolated from Laminaria ochroleuca: a source of new bioactive compounds," Frontiers in Microbiology, vol. 10, p. 683, 2019.

[34] T. Carvalho, M. J. Bibb, M. J. Buttner, K. F. Chater, and D. A. Hopwood, Practical Streptomyces Genetics: A Laboratory Manual, John Innes Centre Foundation, Norwich, UK, 2000.

[35] J. E. M. Stach, L. A. Maldonado, A. C. Ward, M. Goodfellow, and A. T. Bull, "New primers for the class Actinobacteria: application to marine and terrestrial environments," Environmental Microbiology, vol. 5, no. 10, pp. 828-841, 2003.

[36] I. V. Voytsekhovskaya, D. V. Axenov-Gribanov, S. A. Murzina et al., "Estimation of antimicrobial activities and fatty acid composition of actinobacteria isolated from water surface of underground lakes from Badzheyskaya and Okhotnichya caves in Siberia," PeerJ, vol. 6, p. e5832.

[37] F. Timofeyev, S. Nicklen, and A. R. Coulson, "DNA sequencing with chain-terminating inhibitors," Proceedings of the National Academy of Sciences, vol. 74, no. 12, pp. 54635467, 1977.

[38] S. Kumar, G. Stecher, and K. Tamura, "MEGA7: molecular evolutionary genetics analysis version 7.0 for bigger datasets," Molecular Biology and Evolution, vol. 33, no. 7, pp. 1870-1874, 2016.
[39] J. Felsenstein, "Confidence limits on phylogenies: an approach using the bootstrap," Evolution, vol. 39, no. 4, pp. 783-791, 1985.

[40] S. D. Sarker and L. Nahar, Natural Products Isolation, Hum Press, New York, NY, USA, 2012.

[41] S. D. Sarker, L. Nahar, and Y. Kumarasamy, "Microtitre platebased antibacterial assay incorporating resazurin as an indicator of cell growth, and its application in the in vitro antibacterial screening of phytochemicals," Methods, vol. 42, no. 4, pp. 321-324, 2007.

[42] A. Farkas, B. Pap, É. Kondorosi, and G. Maróti, "Antimicrobial activity of NCR plant peptides strongly depends on the test assays," Frontiers in Microbiology, vol. 9, p. 2600, 2018.

[43] E. S. Protasov, D. V. Axenov-Gribanov, Y. V. Rebets et al., "The diversity and antibiotic properties of actinobacteria associated with endemic deepwater amphipods of Lake Baikal," Antonie Van Leeuwenhoek, vol. 110, no. 12, pp. 1593-1611, 2017.

[44] N. L. Bel'kova, V. V. Parfenova, T. Y. Kostornova, L. Y. Denisova, and E. F. Zaichikov, "Microbial biodiversity in the water of Lake baikal," Microbiology, vol. 72, no. 2, pp. 203-213, 2003.

[45] I. A. Terkina, V. V. Parfenova, and T. S. Ahn, "Antagonistic activity of actinomycetes of Lake baikal," Applied Biochemistry and Microbiology, vol. 42, no. 2, pp. 173-176, 2006.

[46] I. A. Terkina, V. V. Drukker, V. V. Parfenova, and T. Y. Kostornova, "The biodiversity of actinomycetes in Lake Baikal," Microbiology, vol. 71, no. 3, pp. 346-349, 2002.

[47] V. V. Parfenova, O. N. Pavlova, I. A. Terkina et al., "Microbial community of the oxidized layer of Lake Baikal bottom sediments in the selenga mouth," Water Resources, vol. 32, no. 2, pp. 204-208, 2005.

[48] S. Qin, J. Li, H.-H. Chen et al., "Isolation, diversity, and antimicrobial activity of rare actinobacteria from medicinal plants of tropical rain forests in Xishuangbanna, China," Applied and Environmental Microbiology, vol. 75, no. 19, pp. 6176-6186, 2009.

[49] R. Li and D. Sipkema, "Marine rare actinomycetes: a promising source of structurally diverse and unique novel natural products," Marine Drugs, vol. 17, no. 5, p. 249, 2019.

[50] D. S. Ningthouja, S. Sanasam, and S. Nimaichand, "Screening of actinomycete isolates from niche habitats in Manipur for antibiotic activity," American Journal of Biochemistry and Biotechnology, vol. 5, no. 4, pp. 221-225, 2009.

[51] A. Van der Meij, S. F. Worsley, M. I. Hutchings, and G. P. van Wezel, "Chemical ecology of antibiotic production by actinomycetes," FEMS Microbiology Reviews, vol. 41, no. 3, pp. 392-416, 2017.

[52] R. F. Seipke, M. Kaltenpoth, and M. I. Hutchings, "Streptomycesas symbionts: an emerging and widespread theme?" FEMS Microbiology Reviews, vol. 36, no. 4, pp. 862-876, 2012.

[53] Z. Zhou, J. Gu, Y. Q. Li, and Y. Wang, "Genome plasticity and systems evolution in Streptomyces," BMC Bioinformatics, vol. 13, no. 10, p. S8, 2012.

[54] J. A. Bland and T. D. Brock, "The marine bacterium Leucothrix mucor as an algal epiphyte," Marine Biology, vol. 23, no. 4, pp. 283-292, 1973.

[55] M. Fletcher and K. C. Marshall, "Are solid surfaces of ecological significance to aquatic bacteria?" Advances in Microbial Ecology, vol. 199, pp. 199-236, 1982.

[56] C. Johnson, D. Muir, and A. Reysenbach, "Characteristic bacteria associated with surfaces of coralline algae: a hypothesis for bacterial induction of marine invertebrate larvae," 
Marine Ecology Progress Series, vol. 74, no. 2-3, pp. 281-294, 1991.

[57] F. Schut, E. J. de Vries, J. C. Gottschal et al., "Isolation of typical marine bacteria by dilution culture: growth, maintenance, and characteristics of isolates under laboratory conditions," Applied and Environmental Microbiology, vol. 59, no. 7, pp. 2150-2160, 1993.

[58] C. B. A. Menezes, R. C. Bonugli-Santos, P. B. Miqueletto et al., "Microbial diversity associated with algae, ascidians and sponges from the north coast of São Paulo state, Brazil," Microbiological Research, vol. 165, no. 6, pp. 466-482.

[59] J. BerlinckFantinatti-Garboggini, M. L. Lemos, and J. L. Barja, "Population dynamics of heterotrophic bacterial communities associated with Fucus vesiculosus and Ulva rigida in an estuary," Microbial Ecology, vol. 15, no. 3, pp. 345-357, 1988.

[60] M. Kanagasabhapathy, H. Sasaki, S. Haldar, S. Yamasaki, and S. Nagata, "Antibacterial activities of marine epibiotic bacteria isolated from brown algae of Japan," Annals of Microbiology, vol. 56, no. 2, pp. 167-173, 2006.

[61] G. M. Zenova, E. O. Omarova, A. I. Kurapova, V. K. Orleansky, and N. V. Shadrin, "The model associations of Cyanoprokaryota and Actinomycetes," International Journal on Algae, vol. 12, no. 3, 2010.

[62] E. O. Omarova, G. M. Zenova, V. K. Orleanskii, and E. S. Lobakova, "Experimental associations of cyanobacteria and actinomycetes," Moscow University Biological Sciences Bulletin, vol. 62, no. 1, pp. 1-6, 2007.

[63] G. Michel, T. Tonon, D. Scornet, J. M. Cock, and B. Kloareg, "Central and storage carbon metabolism of the brown alga Ectocarpus siliculosus: insights into the origin and evolution of storage carbohydrates in Eukaryotes," New Phytologist, vol. 188, no. 1, pp. 67-81, 2010.

[64] P. S. Conville and F. G. Witebsky, "Nocardia, Rhodococcus, gordonia, actinomadura, streptomyces, and other aerobic actinomycetes," Manual of Clinical Microbiology, American Society for Microbiology (ASM), Washington, DC, USA, 2015.

[65] K. M. Mahan, R. K. Le, T. Wells et al., "Production of single cell protein from agro-waste using Rhodococcus opacus," Journal of Industrial Microbiology \& Biotechnology, vol. 45, no. 9, pp. 795-801.

[66] M. M. A. Ragauskas, U. W. Hawas, and M. Jaspars, "Novel bioactive metabolites from a marine derived bacterium Nocardia sp. ALAA 2000," The Journal of Antibiotics, vol. 61, no. 6, pp. 379-386, 2008. 